\title{
The Prevalence and Identification of Gastrointestinal Helminthiasis in Beef Cattle in Lamongan District
}

\author{
Qabilah Cita Kurnia Nastiti Soemarsono $a^{*}$ and Muridi Qomaruddin ${ }^{b}$ \\ $a^{*}, b$ Faculty of Animal Science, Universitas Islam Lamongan, East Java, Indonesia \\ email:qabilahcita@unisla.ac.id
}

\begin{tabular}{l}
\hline A R T I C L E I N F O \\
\hline Article history: \\
Received 14 December 2020 \\
Revised 28 February 2021 \\
Accepted 15 Juny 2021 \\
Available online 15 Juny \\
2021 \\
\hline
\end{tabular}

Keywords:

Prevalence,

Identification,

Helminthiasis

\section{A B S T R A C T}

This study aimed to determine the prevalence and identification of gastrointestinal helminthiasis in beef cattle in Lamongan Regency. The subjects in this study were 100 cow feces divided per district as many as 20 cow feces, saturated sugar solution, PAM water, Aquadest, and 10\% formalin. The stool examination was carried out using three methods as native, sedimentation, and floatation techniques. The result was positive if the analysis on the microscope shows worm eggs in beef cattle feces. The data in this study was presented in quantitative descriptive by calculating the numbers of prevalence. The results showed that the prevalence of gastrointestinal helminthiasis in beef cattle in Lamongan Regency was 24\%. In Kedungpring District, it was 25\%, and Paciran District was 15\%, Sukodadi District was 20\%, Mantup District by 20\%, and Tikung District by $40 \%$. This study concluded that the prevalence rate in Lamongan Regency was $24 \%$. This figure tended to be high because taking the feces was done in the rainy season with high humidity, which was a factor in the high incidence of helminthiasis. Treatment of worms has not been carried out routinely by breeders, and the drums' hygiene was still not right; it was still traditional.
IEEE style in citing this article:

Q.C.K.N. Soemarsono and

M. Qomaruddin " The

Prevalance and

Identification of

Gastrointestinal

Helmintiasis in Beef Cattle

in Lamongan District, Jurnal

Ternak Universitas Islam

Lamongan, vol. 12, no. 1,

pp. 16 - 20, 2021.

Jurnal Ternak (Animal Science Journal) Faculty of Animal science - Lamongan Islamic University) with CC BY NC SA license.

\section{Introduction}

Indonesia is an agricultural country with the majority on farm sector population, one of which is the business of breeding and fattening beef cattle [1]. According to [2], the demand for beef in Indonesia shows an increasing trend every year. The increase in demand for beef cattle is due to community demands for meeting meat's needs as a source of animal protein [3]. Meanwhile, the rate of increasing demand has not been matched with the increase of beef cattle production [4] .The Directorate General of Animal Husbandry stated that in 2007, the rise of beef cattle population was only $4.23 \%$. This condition caused the low supply of beef cattle to national meat production. They resulted in a significant gap between demand and beef production [5]; [6]. In dealing with the increasing demand for meat, the government takes policy steps, namely increasing domestic beef production [7]. Lamongan Regency is one of the leading centers for beef cattle development in East Java. In general, beef cattle cultivation in Lamongan Regency is developed by breeding and fattening. The total population in Lamongan Regency was 117,788 heads in April 2013, with an average annual production of $235,577 \mathrm{~kg}$ of beef. 
The factors that influence the success of this business are food and disease control. One disease that is a chronic problem in tropical countries like Indonesia is helminthiasis or gastrointestinal worm disease. Types of worms that often infecting are Trematoda, Cestoda, and Nematoda classes [8]. [9] states that the prevalence rate of intestinal worms in beef cattle in the Jombang Regency is $59.3 \%$. According to [10] the spread of worm infections occurs relatively high in humid and hot tropical areas, thus supporting these worms' survival. According to Raza et al. (2012), livestock raising management, especially cage sanitation and poor hygiene, is one factor that influences the prevalence of worms. According to [8], several intrinsic factors that also affect worm infectionare age, gender, and breed of cow. Young cows, especially between one to three months, are susceptible to disease with Toxocara Vitulorum, because colostrum from the mother does not protect against the infection of these worms [11]. The body's immune response to worm infections in adult cows is better than that of young cows.

In Lamongan regency, the types of crossbreed cattle that have been kept by many residents are PO, Limousine, and Simental cattle. Most of the population in the Lamongan Regency still traditionally raises cows. The beef cattle pen is behind the house with a semi-permanent building. There is no drain for livestock feces and urine, so that the sanitation of the stables is not maintained. Tikung district is geographically surrounded by reservoirs, which are lowlands and often flooded during the rainy season, where the water is suitable breeding medium for digestive tract worms and transporting worm eggs.

The losses due to gastrointestinal worm disease are weight loss, decreasing in quality of meat, skin, meat, reducing livestock productivity, reducing milk production in dairy livestock, and the danger of transmission to humans or zoonoses [12]. Digestive tract worm disease in animals is a disease that affects livestock productivity and generally does not cause death, but is chronic in nature, which can lead to thinness, weakness, and decreased production power. Mild to moderate worm infections do not always show obvious clinical symptoms, while severe disease from adult worms causes digestive disorders and stunted the growth in young livestock [11].

Based on the above background, it is necessary to research the prevalence and identification of gastrointestinal helminthiasis in beef cattle in the Lamongan Regency. By knowing the type of worm that is infecting, treatment can be done immediately with the right kind of antiparasitic drug to become more effective. Hopefully, the worm disease incidence data can be used in the effort to eradicate worms, in the context of developing beef cattle farms and reducing the losses incurred.

\section{Material and Methods}

\subsection{Research Materials}

The study used a fresh sample of beef cattle feces. Other materials used for the examination are saturated sugar solution, PAM water, Aquadest, and 10\% formalin.

\subsection{Research Equipment}

The research equipment were: plastic cups, stirring glass plastic bags, centrifuge tubes, centrifuges, object-glass, cover glass, microscopes, scales, and pasteur pipettes.

\subsection{Collection of Feces}

100 samples of feces were collected from 5 different places, in Tikung district, Mantup district, Kedungpring district, Sukodadi district, and Paciran district. The method of collecting fecal samples was the feces of each beef cattle. Each defecated cattle were observed and marked with a spray tint on its leg. Fresh stool samples were taken using a plastic bag, given $10 \%$ formalin, and then checked. 


\subsection{Stool Examinations by Native or Simple Methods}

Feces were taken a little by using the tip of a stirring glass and smeared on the objectglass, then added a drop or two of water, then flattened and covered with a glass cover. The examination was carried out with a 100x magnification microscope [13].

\subsection{Stool Examinations by Sedimentation Method}

The feces were put in a plastic glass and then added water with a ratio of 1:10. Feces and water were stirred until evenly distributed and then filtered; the filter results were put into a centrifuge tube and then centrifuged for 3 minutes at a speed of $1500 \mathrm{rpm}$. After being centrifuged, the supernatant was discarded. While the sediment was added with water again as in the previous stage then centrifuged for 3 minutes at a speed of $1500 \mathrm{rpm}$, the process was repeated three times or until it was clear. Afterwards, the supernatant was removed until the remainder was small and stirred. The precipitate was taken one drop with a pipette and placed on a glass object, then covered with a glass cover and examined under a microscope with 100x magnification [13].

\subsection{Stool Examinations Using the Floating Method}

The feces were put into a plastic glass, and then added water with ratio of $1 ; 10$. The feces and water were stirred, then filtered. The filter results were put into a centrifuge tube for 3 minutes at a speed of $1500 \mathrm{rpm}$. After the centrifuged process, the supernatant was discarded, and the sediment was added with water once more as in the previous step, then centrifuged again for 3 minutes at a speed of $1500 \mathrm{rpm}$; the process was repeated until the supernatant was clear. After the supernatant was clear, it was removed, and the sediment was added with a saturated sugar solution to approximately $2 \mathrm{~cm}$ from the mouth of the tube then stirred with a stirring glass, then centrifuged at $1500 \mathrm{rpm}$ for 3 minutes, then gradually added the saturated sugar solution using a pasteur pipette until the liquid surface was convex. The examination results were positive if in one, or both, of the three methods mentioned above, worm eggs are found [11]. Identification of ruminant digestive tract worm eggs was based on [14].

\subsection{Data Analysis}

If the examination of a positive stool sample was found worm eggs, then to find out the prevalence, it was calculated using the following formula:

\section{Prevalence $=\underline{\text { Total infected }} \times 100 \%$ \\ Total population}

\section{Results}

From the analysis of 100 samples of beef cattle feces in Lamongan regency, there were 24 positive samples containing worm eggs with a prevalence of $24 \%$. From 20 samples of beef cattle feces in Kedungpring district, there were 5 positive samples with a prevalence of $25 \%$. From 20 samples of beef cattle feces in Paciran subdistrict there were 3 positive samples with a prevalence of $15 \%$. From 20 samples of beef cattle feces in Sukodadi district, 4 positive samples were found with a prevalence of $20 \%$. From 20 samples of beef cattle feces in Mantup district, 4 samples were positive with a prevalence of $20 \%$. From 20 samples Beef cattle feces in Tikung district, there were 8 positive samples with a prevalence of $40 \%$. The prevalence percentage of gastrointestinal helminthiasis in beef cattle in Lamongan regency that was found during the study is presented in Table 1. 
Table 1. Prevalence of Gastrointestinal Helminthiasis in Beef Cattle in Lamongan Regency

\begin{tabular}{llcccc}
\hline No. & \multicolumn{1}{c}{ District } & Total Sample & $\begin{array}{c}\text { Positive } \\
\text { (Sample) }\end{array}$ & $\begin{array}{c}\text { Negative } \\
\text { (Sample) }\end{array}$ & Prevalence (\%) \\
\hline 1. & Kedungpring & 20 & 5 & 15 & 25 \\
2. & Paciran & 20 & 3 & 17 & 15 \\
3. & Sukodadi & 20 & 4 & 16 & 20 \\
4. & Mantup & 20 & 4 & 16 & 20 \\
5. & Tikung & 20 & 8 & 12 & 40 \\
& TOTAL & 100 & 24 & 76 & 24 \\
\hline
\end{tabular}

The prevalence rate of gastrointestinal helminthiasis in beef cattle in Lamongan regency of $24 \%$ was high. This was due to the rainy season while the samples were taken. The humidity was high, the amount of standing water in the sampling area, and the number of plants around the cage helped various types of worms continue their life cycle. Indonesia is a tropical area as a perfect place for the development of worms, so the cases of parasitic infection by worms in animals in Indonesia were high [15]. The rainy season is good for the development of worm eggs and larvae, so that the incidence of helminthiasis is more common in the rainy season than in the dry season [11]. Feces have an extensive role in spreading helminthiasis because they can directly contaminate food, water, and soil. Inappropriate management, harmful environments such as wet cage floors, lack of hygiene at times, and the number of animals in a population can affect the transmission of helminthiasis in healthy animals so that it affects the high prevalence rate [11]. Control and treatment of worm disease on an ongoing basis are also almost the same in Lamongan regency.

Based on the examination results, it was found that 5 positive stool samples contained digestive tract worm eggs from 20 samples of beef cattle feces taken from Kedungpring district with a prevalence of $25 \%$. The prevalence rate was high because the average beef cattle in Kedungpring district still had no deworming medication. There were 3 positive stool samples containing digestive tract worm eggs from 20 samples of beef cattle feces taken from Paciran district with a prevalence of $15 \%$. This prevalence rate was the lowest compared to other sub-districts because the average beef cattle in Paciran subdistrict had been given worm medicine. The weather factor also affected because Paciran district has a higher temperature so that the humidity is lower.

The control and prevention of helminthiasis by administering worm medicine have mainly been carried out. The prevalence rate of helminthic cases in Paciran was the lowest compared to other districts. There were 20 samples of beef cattle feces taken from Sukodadi district, there were 4 positive samples containing worm eggs, so the prevalence rate was $20 \%$. This was the same as the results of an examination of feces samples taken from the Mantup district. The highest prevalence rate based on analysis of feces samples was from Tikung District, recorded as $40 \%$. Based on the examination result, there were 8 positive stool samples containing worm eggs from 20 samples of beef cattle feces. The sampling for this study was conducted in September in the rainy season. In that season, the reservoir water in Tikung subdistrict often overflowed and flooded the Tikung subdistrict. The soil on the cage was in a humid and muddy condition. Therefore, it is common to find digestive tract worm infections in beef cattle in Tikung district, Lamongan regency. Moist areas are suitable conditions for the growth of various types of worms.

\section{Conclusion}

The prevalence of gastrointestinal helminthiasis in beef cattle in Lamongan Regency was $24 \%$. This prevalence rate tended to be high due to the high humidity incidence when feces were collected 
during the rainy season. Treatment of worms had not been carried out routinely by breeders, and the drums' hygiene was still not right; it was still traditional.

\section{References}

[1] P. Arbi, "Analisisa Kelayakan Dan Strategi Pengembangan Usaha Ternak Sapi Potong," Progr. Stud. Agribisnis Dep. Sos. Ekon. Pertanian. Fak. Pertanian. Univ. Sumatera Utara. Medan. Skripsi, 2009.

[2] D. Priyanto, "Strategi pengembangan usaha ternak sapi potong dalam mendukung program swasembada daging sapi dan kerbau tahun 2014," 2016.

[3] R. Yusuf, "Kandungan protein susu sapi perah friesian holstein akibat pemberian pakan yang mengandung tepung katu (Sauropus androgynus (L)(Merr) yang berbeda," J. Teknol. Pertan., vol. 6, no. 1, hal. 1-6, 2010.

[4] I. Subagyo, "Potret komoditas daging sapi," Econ. Rev., vol. 217, hal. 32-43, 2009.

[5] R. Mersyah, "Desain sistem budi daya sapi potong berkelanjutan untuk mendukung pelaksanaan otonomi daerah di Kabupaten Bengkulu Selatan," Disertasi, Sekol. Pascasarjana, Inst. Pertan. Bogor, 2005.

[6] W. P. Santi, "Respons Penggemukan Sapi PO dan Persilangannya sebagai Hasil IB terhadap Pcmberian Jerami Padi Fermentasi dan Konsentrat di Kabupaten Blora," Skripsi. Fak. Peternak. Inst. Pertan. Bogor, 2008.

[7] M. A. Bambang, "Beternak Sapi Potong," Penerbit Kanisius. Yogyakarta, 2002.

[8] M. A. Raza et al., "Point prevalence of gastrointestinal helminthiasis in Buffaloes (Bubalus bubalis) at The Vicinity of Jatoi, Punjab, Pakistan," Sci. Int.(Lahore), vol. 24, no. 4, hal. 465-469, 2012.

[9] T. D. Setiyono, Understanding and modeling soybean (Glycine max., L. Merr.): Growth and development under optimum conditions. The University of Nebraska-Lincoln, 2007.

[10] I. Yulianto, R. Hall, B. Clements, dan C. R. Elders, "Structural and stratigraphic evolution of the offshore Malingping Block, West Java, Indonesia," 2007.

[11] S. Koesdarto, S. Subekti, S. Mumpuni, dan H. P. dan Kusnot, "Buku Ajar Ilmu Penyakit Nematoda Veteriner," Fak. Kedokt. Hewan, Univ. Airlangga, Surabaya, 2007.

[12] L. C. Gasbarre, E. A. Leighton, dan T. Sonstegard, "Role of the bovine immune system and genome in resistance to gastrointestinal nematodes," Vet. Parasitol., vol. 98, no. 1-3, hal. 51-64, 2001.

[13] M. Mumpuni, T. Chikmawati, dan T. N. Praptosuwiryo, "Poliploidi intraspesifik Pteris Vittata L.(Pteridaceae) di Pulau Jawa," Floribunda, vol. 5, no. 2, 2015.

[14] M. E. Soulsby, J. B. Barnett, dan S. Maddox, "The antiseptic efficacy of chlorxylenol-containing vs. chlorhexidine gluconate-containing surgical scrub preparations," Infect. Control Hosp. Epidemiol., vol. 7, no. 4, hal. 223-226, 1986.

[15] I. Beriajaya dan D. B. Copeman, "Seasonal differences to the effect of nematode parasitism on weight gain of sheep and goats in Cigudeg, West Java," J. Ilmu Ternak dan Vet., vol. 2, no. 1, hal. 66-72, 1996. 